\title{
Selected Ngos and Poverty Reduction in Makurdi Local Government Area of Benue State, Nigeria
}

\author{
Vincent Iorja Gisaor \\ Department of Economics, Federal University Wukari, Taraba State, Nigeria \\ Email: gisaorvincnet@gmail.com
}

\begin{abstract}
The research was undertaken to access the impact of Non-Government organizations (NGOs) on poverty reduction in Makurdi local government area of Benue State. Using descriptive approach to analyze the primary data obtained from the respondents through a structured questionnaires and semi-structured interview administered to the staff and officials of selected NGOs in the study area. Result shows that the respondents confirm benefits in terms of increased income, use of good transportation means, good accommodation, feeding and sleeping materials. Despite these benefits, there were challenges confronting the NGOs in the study area. One of the biggest challenges was finance to execute all their programmes as well as disburse to beneficiaries as loans and grants. The activities of NGOs were found only limited to Makurdi while the majority of the people were residing outside the state capital. Therefore, recommendations made include: awareness creation for more participation by people in entrepreneurship and financial independence since it is only through such skills that they can propel themselves out of poverty and the NGOs should seek for more sources of funding including soliciting financial support from the international community to enable it fund diversified economic activities of the vulnerable people in the country.
\end{abstract}

Keywords: non-governmental organizations, poverty reduction, makurdi LGA, nigeria

\section{Introduction}

There is no doubt about the fact that Nigeria is richly endowed with abundant human and material resources (Anyanwu, 1997 and Gisaor, 2016). In spite of these riches, it has been classified as one of the poorest countries of the world in terms of its Gross Domestic Product (GDP), per capita income, consumption standards, provision and availability of basic needs, shelter, poverty, unemployment and overall economic performance (Umoh and Ibanga, 1997). Beyond Nigeria, the concern for poverty is also expressed at the global level (Gisaor, 2016). The International Monetary Fund (IMF), (2020) and Central Bank of Nigeria (CBN), (2010) particularly reported that about 1.2 billion people were in extreme consumption poverty globally. More than two thirds of them were in Asia and about one quarter in Sub Saharan Africa.

Poverty is a state where an individual is not able to cater adequately for his or her basic needs of food, clothing and shelter; being unable to meet social and economic obligations (Gisaor, 2016). It means lack of gainful employment, skills for self-reliance, assets and self-esteem and having limited access to social and economic infrastructure such as education, health, portable water, and sanitation; and consequently, has limited chance of advancing his or her welfare to the limit of his or her capabilities (Betiang, 2010). It is quite difficult to completely eradicate poverty globally and nationally. Therefore, in most cases, certain segments of the society are targeted with the hope of making an overall impact. As such, all formal activities geared towards lowering the rate and prevalence of poverty in the country are considered as poverty reduction. Poverty reduction strategies are a position introduced in many countries by the World Bank; that is a development plan borne out of collaborative efforts of a broad range of stakeholders in poverty reduction. It is normally designed and implemented through the participation of all involved in one way or the other in poverty reduction and in other related 
issues (Royemomi, 2013).

One of these stakeholders is the Non-Governmental Organizations (NGOs), a private and nonprofit organization that collaborates with the developing countries in order to alleviate their suffering, fight for the interests of the poor, protect the environment, provide basic social services and seek community development (Gisaor, 2020). NGOs are a modern phenomenon, born after the Second World War and that during the 1970s had an evolution, from humanitarian NGOs to NGOs for development. This means that their initial focus on humanitarian aid gradually changed to refugees and the denunciation of poverty which came as a consequence of the world economic order (Mauri, 2013). NGOs are non-profit institutions, independent from government, many of them having an activity of solidarity and cooperation with the poorest countries in the world. They promote actions and projects, together with the local people and organizations, thus contributing so that these countries and the participants in particular are actors of their own development (Gisaor, 2020 and Mauri, 2013). NGOs often create close links with grassroots organizations, and often do the role of intermediary between government and community providing technical advice or financial support to the people.

Royemomi (2013) believed that at the provincial, national and local level, without the requirement of action of partners like NGOs, there will not be enough capacity for rapid poverty reduction. The NGOs and some other religious organizations have a very important role in combating poverty. In Nigeria in general and Benue State in particular, there is evidence from Stewart (2003) and Gisaor (2016) about the role of NGOs and the faith based organizations in alleviating poverty among the populace. There are over 21 NGOs in Makurdi including the Ojireh Foundation, Youth Empowerment Foundation, Mama Ngihuan Foundation, Eunice Spring of Life, etc, specializing and undertaking different poverty reduction activities like skill acquisition, economic empowerment, disease control and management: Adult literacy scheme and capacity building and information driven charity, conflict resolution and peace promotion (Gisaor, 2020).

These NGOs have also provided microcredit and training to many Nigerians. According to Gisaor (2020) and Ahemen (2011), while a good number of NGOs in Nigeria have focused on the declining state of agricultural inputs and poverty, others have centred on empowerment and poverty. The focus of NGOs in the provision of support and in alleviating poverty has made them the best reliable alternative institutions for people in terms of improving their socio-economic conditions. In spite of this, poverty continues to rear its ugly head among the people. What then is the incidence, depth and severity of poverty among youth in the study area, and what is the impact of the NGOs on poverty reduction in the study area? In the bid to provide useful answers to the questions above, this study is set out to empirically examine the role of NGOs in poverty reduction in Makurdi Local Government Area of Benue State. The study is limited to the activities of the NGOs in Makurdi Local Government Area of Benue State where over 10,000 participants have been recorded between 2007 and 2020.

\section{Literature Review}

\subsection{Conceptual Framework}

\subsubsection{Non-Governmental Organization (NGO)}

A number of approaches or perspectives have evolved over the years, geared towards the actualization of community development. One of the most popular approaches is the 
provision of basic social amenities to communities by government. Others include: Community Development Associations (CDA): that does initiate, mobilize resources and execute community project. Cooperative Societies: they mobilize credit facilities for members and build small scale industries in the community. Community Elites: These are individual community members or groups, who support the community in areas of felt needs as well as influence the government and other development agencies in sitting of projects in their communities. And the most recent in the course of institutionalizing stakeholder participation in community development is the Non-Governmental Organisation (NGO). In its broadest sense, the term NGO refers to organizations (i) not based on government; and (ii) not created to earn profit. The terminology of an NGO varies itself: for example, in the United States they may be called private voluntary organizations, and most African NGOs prefer to be called voluntary development organizations (Gisaor, 2020).

The diversity of NGOs strains any simple definition. They include many groups and institutions that are entirely or largely independent of government and that have primarily humanitarian or cooperative rather than commercial objectives. They are private agencies in industrial countries that support international development; indigenous groups organized regionally or nationally; and member-groups in villages. NGOs include charitable and religious associations that mobilize private funds for development, distribute food and family planning services and promote community organization (IMF, 2020). They also include independent cooperatives, community associations, water-user societies, women's groups and pastoral associations. Citizen Groups that raise awareness and influence policy are also NGOs.

\subsubsection{NGOs and the Host Government/Community}

NGOs are often polarised with local and national governments, but such a dichotomy overlooks the nature of relationships between the two, which can range from overt and hidden tensions and active hostility to cooperation and collaboration, depending on multiple influences such as successive government regimes and their dispositions and changing NGO strategies and interventions (Gisaor, 2016 and Rose, 2011). While there is scope for positive relationships between government and NGOs for those working towards mutual goals in service and welfare provision, those working openly in advocacy and human rights tend to be viewed with suspicion or open hostility, especially when explicitly challenging the state. In Pakistan, for example, Nair (2011) highlights the potential for collaboration when NGOs remain in predefined roles of service provision, but the generation of conflict when NGOs step outside these to question government policies. While collaboration and strong linkages with national governments assists programme sustainability, where interests of the state and NGOs increasingly coincide, this runs the risk of pushing out the interests of those they are both responsible to, the poor (Rosenberg, 2008).

Prevailing institutional arrangements underpin the emergence and proliferation of NGOs in developing countries, ensuring that every country's NGO sector is different and distinctive (Lewis, 1998). Diverse and complex, relations between governments and NGOs vary considerably from country to country and region to region. In South Asia, Nair (2011) traces the evolutionary history of relationships between the state and NGOs in Bangladesh, India and Pakistan, finding that a mixture of socio-political environments, NGO activities, donor presence and agendas, and global policies and pressures have influenced government-NGO relationships to varying degrees across the three countries. A withering of formal 
representative institutions fuelled the explosion of NGOs in India, with political parties since the 1970s being increasingly dismissive of excluded castes and groups (Clarke, 1998). Likewise, in the Philippines, too, the inability of political parties to secure representation and participation for a large proportion of the population created an institutional vacuum into which NGOs stepped (Clark, 1998). In contrast, NGOs in the East Asian countries of Indonesia and Vietnam proliferated in response to state hegemony rather than the weakness of formal institutions, attempting to expand the limited political space available to civil society (Clark, 1998). Characterised by its history of active associational life in which indigenous membership based organisations have long played a role in community life and development (Hearn, 2007).

Africa experienced its NGO boom a decade later, starting in the 1990s. Kenya, for example, experienced a rapid increase in registered NGOs from 400 in 1990 to over 6,000 in 2008 (Brass, 2011). Likewise in Tanzania, the 41 registered NGOs in 1990 have increased to more than 10,000 by 2000 (Hearn, 2007). In some countries such as Nigeria, Ethiopia and Uganda, the NGO sector is viewed with mixed feelings, including rampant suspicion that the public good is not the primary motivation fuelling NGOs. Political influences have been suggested as a strong influence on NGOs in Africa, with NGOs joining the patronage networks of political leaders (Brass, 2012).

In Latin America, NGOs have historically functioned in opposition to the government, playing a crucial role in strengthening civil society (Drabek, 1987). Consequently, the NGO sector here emerges from a stronger and more radicalised body of civil society organisations in opposition to the authoritarian regimes across the region. In this original form, community development was seen as a secondary goal, justified only on the basis of serving the higher goals of social change. These popular movements, have, over time, experienced fragmentation, weakening, and identity crisis (Gill, 1997). Transitions to democracy throughout the region meant NGOs could no longer base their identity purely on resistance, and a distortion in incentives fostered by foreign aid exacerbated pressures on NGOs to move towards greater collaboration with government in service provision (Gill, 1997 and Clark, 1998).

\subsubsection{Poverty, Types and Causes}

Anyanwu (1997) defined poverty as the state where an individual is not able to cater adequately for his basic needs. Basic needs such as food, clothing, shelter, meeting social and economic obligations, lack of gainful employment, assets and self-esteem, limited access to social and economic infrastructures such as education, health, portable water and sanitation, and as a result has limited chance of advancing his/her welfare to the limit of his/her capabilities. Oriola (2006) on his part see poverty as the inability to attend to, or meet up with the basic necessities of life as a result of lack of resources to do so. That is to say, poverty is exhibited by a lack of material well-being, insecurity, social isolation, psychological distress and low self-confidence, lack of freedom of choice, action and unpredictability.

A comprehensive definition of poverty was given by the World Bank (2003) when it succinctly defined poverty as hunger, lack of shelter, being sick and not being able to go to school, not knowing how to read, not to speak properly, not having job, having fear of the future, losing a child to illness brought about by unclean poverty. This definition of the World Bank was supported by the UNDP (2004) when it defined poverty in terms of the absence of basic requirement essential for survival, and to an extent, the comfort of man. It is hunger and 
starvation, squalor and non-availability of basic Medicare. For the purpose of this work, poverty is defined as a situation whereby an individual is unable to provide for himself the basic necessities of life such as food, shelter and health, clothing, education and unable to contribute meaningfully to the social economic growth of the immediate environment.

According to Anyanwu (1997), economists have categorized poverty in terms of absolute, relative, chronic, transient and mass poverty. But in whatever form it is experienced, poverty inflicts both real and psychological pains on its victim. There are some techniques used for measuring poverty. These include the head count index, the Lorenz curve, the adult-equivalent scale, the Gini-coefficient, the poverty gap index, the Human Development Index (HDI), dollar per day measure, p-alpha etc. Each of these techniques with application of various statistical methods can be used to determine the extent and severity of poverty.

Absolute Poverty is a condition where a person or a group of people are unable to satisfy their most basic and elementary requirements for human survival such as food, clothing, shelter, health and education (Mohammed, 2008). Relative Poverty referred to the poverty position of an individual relative to other individuals in the same society. Chronic Poverty according to Anyanwu (1997) is poverty that is more permanent in nature and depends on a host of factors such as limited employment, location disadvantage, cultural and gender factors. Transitory Poverty describes poverty that is temporal and caused by transients factors such as natural and man-made disasters such as war, environmental degradation and policy features in government. Mass Poverty describes a poverty situation where the general masses or majority of the population are poor. The World Bank (2003) recognized several measures of poverty such as poverty line, poverty profile and indicators. For the purpose of this work, we shall use the poverty line, because of importance attached to it by the World Bank and other financial agencies. Poverty line is the value of income or consumption necessary for the minimum standard of nutrition and other necessities. The World Bank (2003) defined it in terms of $\$ 1$ per day. It is therefore the cut-off living standard below is poor and above is non-poor. In the context of this work, poverty line is $\$ 1$ per day transformed to $\$ 470.00$ in Nigerian official exchange rate.

\subsubsection{Role of NGOs in Alleviating Poverty}

The literature on issues of development has recognized three important actors in the development process. They are: the state, the private sector and the Non-Governmental Organizations sector, which is also known as the third sector. Following the crisis of the development theories of the 1960s and the 1970s, the newly appearing paradigms of development have begun to shift the focus more from economic growth to a sustainable human centred development (Gisaor, 2020). These new paradigm implies the participation of people in all stages of the development process including planning and decision-making. Enhancement of people's participation in turn implied an empowerment process by which individuals, groups and organizations develop their capacities to perform various social functions. The new paradigms of development call for the promotion of democratic cultures and systems as an important precondition for social and economic development. An independently functioning civil society can contribute to good governance and the respect of human rights, which in turn are increasingly recognized as important conditions for development. Since recently NGOs in many countries have gained a fraction of credibility as actor of the development effort. NGOs have continued to grow both at an international and local level and have also increased in their diversity (Gisaor, 2016). 
NGOs have made greater efforts to promote participatory approaches. The government now says it is committed to the participatory approach but it is debatable whether this is the influence of the NGOs. In contrast, state structures including those charged with managing development programs have become more bureaucratic in the last two or more decades, and few state officials are willing to consider innovative approaches to program design and management. Finally, NGOs do operate in the more inaccessible parts of the country, but so does the government; there is hardly any NGO site that does not have a government presence (Mohammed, 2008). Bratton has argued that voluntary institutions in Africa have broadened their interventions in the period since the 1970s to fill the gap left by the state. He talks about the "retreat of the African state" creating opportunities for the growth and influence of civil society (Gisaor, 2016). NGOs have long been active in the development field and have gained increasing prominence in recent years.

Women and youths NGOs have been no exception to this general rule. Throughout the 1980s, as the efficacy of central planning came under question and as the ideological discrediting "the state" gained momentum, NGOs were embraced by donor governments and multilateral funding agencies as partners in development. This has change the role of governments and multilateral funding agencies as partners in development. This shift in thinking was also reflected in the growing proportion of development funding handed by the NGO sector. In Africa, for instance, about half of World Bank development fund for 1993 were channelled through NGOs (Mauri, 2013). At the same time, there has been a significant change in the development agenda away from a preoccupation with economic issues towards an emphasis on political and institutional problems. Human rights, good governance and participation have thus gained prominence (Gisaor, 2020 and Mauri, 2013).

The emphasis on NGOs entailed a number of contradictory implications. On the one hand, the early and current critique of project approach by some of these advocates and the efforts at mainstreaming gender at the macro-economic level seem to be at odds with the NGOs approach to development, which is essentially project oriented. On the other hand, the rhetoric of "empowerment" and bottom-up development" has much appeal, for reasons that are explained below. In fact, as was noted in the previous section, women and development advocates differ in the extent to which they see the role for NGOs and collective action in part as a reflection of their underlying assumptions about the nature of women's subordination. Those using social relations analysis, for example, tend to see a more critical need for empowerment strategies at the grassroots level while gender efficiency advocates rely more heavily on changing the conceptual frameworks used by planners and policy makers (Brass, 2012).

Within the NGO sector, a rich diversity of paradigms continued to influence development practice. The empowerment approach remained particularly strong. The continuous pressure applied by organized women, youths and children groups remained significant focusing governments and other agencies to take these vulnerable groups more seriously and address their concerns. Although some shifts occurred in rhetoric and practice, NGOs remained the dominant approach of governments, relief and development agencies and bilateral donor agencies (Mohammed, 2008). By so doing, they are able to contribute to participatory development and they are able to expose the government to a grassroots perspective, which might otherwise be neglected. However, there might be increased risk of corruption, reduced independence, and financial dependency (Brass, 2012). It is within this context that the relevance and significance of NGOs have grown in time. Today, NGOs are accepted as one of 
the three important actors. Indeed there is an ever-growing interest nowadays in NGOs as development agencies at all levels. In this process, NGOs also have grown in their size and nature with more potential as development actors (Mauri, 2013).

\subsection{Theoretical Framework}

There are various theories supporting this study. It is however very important to consider only the theory that is mostly applicable to this work, the vicious circle of poverty. The vicious cycle theory was propounded by Ragner Nurkse in 1960 and it upholds that "there is a circular constellation of forces tending to act and react upon one another in such a way as to keep a poor person, society or country in a state of poverty". The theory explains that a poor man may not have enough to eat, being underfed, his health may be weak, being physically weak and his working capacity is low, which means that he is poor. According to Jhingan (2007), the basic vicious circle stems from the fact that Less Developed Countries' (LDCs) total productivity is low due to deficiency in capital, market imperfection, economic backwardness and underdevelopment. Thus, the vicious circle tends to perpetuate the low level of development in LDCs. The vicious circle operates on both demand and supply side. There is also a third vicious circle which envelops from underdeveloped human and natural resources owing to poor technology, poor entrepreneurial activity resulting into un-utilized natural resources.

\subsection{Empirical Review}

Oke and Adeyemo (2007) wrote on the impact of Non-governmental Organizations on rural poverty alleviation in South-western Nigeria. Multi-stage stratified random sampling procedure was used to collect data from 200 clients and 200 non-clients of NGOs in the study area. Using linear multiple regression model, the results from Forster-Greer-Thorbecke indices showed that poverty depth and severity among the non-clients were higher than among the client. It also showed that belonging to the clients' group alleviated poverty as well as enhanced savings of respondents. The study concludes that microfinance delivery efforts of the NGOs enhanced poverty alleviation among clients in the area. Omofonmwan and Odia (2009) wrote on the role of Non-governmental organisations in community development in Edo State in Nigeria using interview, observations, intensive local field studies and extensive travel throughout the state. The findings includes: a number of these NGOs were into various aspects of community development such as: community mobilization, environment, health and sanitation awareness creation, promotion of child's rights law, promotion of sexuality and reproductive health education and fight against child labour and human trafficking.

Hulme and Nicola (2012) studied the role of NGOs in poverty reduction in Manchester. Using some selected NGOs and 5000 respondents, the result shows positive impact of NGOs on poverty reduction in the study area. They however, recommended a shift away from their role as service providers to that of facilitators and supporters of broader civil society organisations through which low-income communities themselves can engage in dialogue and negotiations to enhance their collective assets and capabilities. Newman (2012) assessed the role of nongovernmental organizations (in rural development in Rivers State. Six NGOs were selected randomly for detailed investigation and relevant information was collected by personal visits and questionnaire administration to 100 beneficiaries and 100 non beneficiaries. The overall analysis of the study reveals that NGOs were very prominent in effective implementation of government programmes towards sustainable rural development through the third party 
activities in education, health, agriculture, community development, energy, environment, and waste, moral upbringing, youth empowerment and poverty alleviation.

Devi (2013) assessed the role of NGOs in poverty reduction in India. He selected six out of many NGOs while 200 respondents who have benefited from the activities of the NGOs were sampled. Using descriptive data analysis, the result shows that NGOs were working basically to eradicate poverty and empower the people in the selected areas. He recommended that the NGOs should strengthen their programs to address the strategic needs of poor with a view to providing basic social services as well as fulfilling practical needs. Beto and Leonorah (2016) evaluated the role of NGOs on poverty reduction in Mozambique using interviews and focus group discussions, the findings reveal that despite the existence of NGOs, the reduction of poverty has been minimal and it was found that Zambézia Province has experienced poor environments in terms of infrastructure, poor education and skills, poor health and nutrition. The study recommends that poverty reduction programmes must be properly addressed and more involvement of all stakeholders like local community, NGOs and sectors of civil societies among others. Empirically, the researcher found it difficult to come across a study on the role of NGOs in poverty reduction in Benue State in general and Makurdi Local Government Area in particular especially now that poverty is on the increase with worsening economic fortunes in the wake of recession. This work would thus fill this empirical vacuum.

\section{Research Method}

This research was conducted in Makurdi local government area of Benue State. The town has recently witnessed the springing up of businesses in the area of hospitality, sachet water companies, business centers and a host of small and medium enterprises have also been on the increase. There are commercial bus drivers, taxis and motorcycle drivers popularly known as Okada drivers as the biggest means of transportation from one point to another. There are almost all commercial banks branches located in the town and a numbers of NGOs also exist to cater for different needs of the people of the local government.

Case study research design was chosen because NGOs are prevalent in the country with peculiar impact on the living standard of the people. Report from the NGOs selected for study indicates that over 10,000 people have already registered and participated in their poverty reduction activities. Out of this figure, only 2,001 have successfully participated and benefited over the years. The study population thus becomes 2,001 respondents. The beneficiaries selected are already stratified into a sampling frame known as beneficiaries of the NGOs. The sample size is statistically determined by using Taro Yamane formula at the significant level of $95 \%(0.05)$

$n=\frac{\mathrm{N}}{1+\mathrm{N}\left(\mathrm{e}^{2}\right)}$

Where; $n=$ sample size, $\mathrm{N}=$ population under study (2,001 respondents), $e=$ margin of error $(0.05)$ and $1=$ constant

It follows that: $n=\frac{2,001}{1+2,001\left(0.05^{2}\right)}=\frac{2,001}{1+2,001(0.025)}=\frac{2,001}{1+50.025} \frac{2,001}{51.025}=39.221$

Therefore our sample size is approximately 40 respondents as beneficiaries in the NGOs. Each NGO now constituted a sampling block where questionnaires were given to those who have benefitted from their various poverty reduction activities. A semi structured interview was conducted on the officials of the NGO to further confirm the views of the beneficiaries on the impact of the NGOs in poverty reduction in the state. A descriptive technique of data 
analysis was be adopted hence data was neatly presented in tables, charts, graphs and other relevant pictorial representations.

\section{Findings and Discussions}

\subsection{Data Presentation}

Table 1. Sex Distribution of the Respondents

\begin{tabular}{|l|c|c|}
\hline Sex & Number of Respondents & Percentages (\%) \\
\hline Male & 28 & 70 \\
Female & 12 & 30 \\
Total & 40 & 100 \\
\hline
\end{tabular}

Source: Field Survey, 2021

Table 1. above shows that 28 respondents representing $70 \%$ out of the total respondents of 40 sampled were male while 12 or $30 \%$ of the respondents were female. This clearly shows that the male population dominated in the poverty reduction activities of Youth Empowerment and Development Foundation in the study area. This is a confirmation of the usual culture and practice in the country where the male are assumed to represents their family and as such nothing is done to encourage the female population to participate in economic activities. This has actually put so many women and children in a vulnerable position in terms of social ills such as poverty and unemployment. Marital status is one of the major demographic factors capable of influencing ones participation in any enterprise. Table 2 . below indicates that 28 respondents sampled corresponding to $70 \%$ of the respondents were single while 10 respondents corresponding to $25 \%$ of the respondents were married and 2 respondents or $5 \%$ were divorced. This implies that the single people dominated in the activities of the NGO in the study area.

Table 2. Marital Status of the Respondents

\begin{tabular}{|l|l|l|}
\hline Marital Status & Number of Respondents & Percentages (\%) \\
\hline Single & 28 & 70 \\
Married & 10 & 25 \\
Divorced & 2 & 5 \\
Total & 40 & 100 \\
\hline
\end{tabular}

Source: Field Survey, 2021

Table 3. Age Distribution of the Respondents

\begin{tabular}{|l|l|l|}
\hline Age & Number of Respondents & Percentages (\%) \\
\hline $18-30$ & 30 & 75 \\
$31-45$ & 10 & 25 \\
\hline
\end{tabular}




\begin{tabular}{|l|l|l|}
\hline $46-65$ & - & - \\
$66+$ & - & - \\
Total & 40 & 100 \\
\hline
\end{tabular}

Source: Field Survey, 2021

Age is perceived to be an important variable that determines the nature of economic activities that can be undertaken by an individual. Table 3 above reveals that $75 \%$ of the respondents sampled aged between $18-30$ years and $25 \%$ of the respondents were between the ages of 31 45 years. None of the respondents were between the ages of $46-65$ and above 65 years. On the whole, $100 \%$ of the respondents fall within the economically active age brackets of 18-45 years. This is a further confirmation of the primary objective of the NGOs which is to reduce poverty among the youth in the study area.

Table 4. Educational Status of the Respondents

\begin{tabular}{|l|l|l|}
\hline Educational Status & Number of Respondents & Percentages (\%) \\
\hline Primary & 5 & 12.5 \\
Secondary & 10 & 25 \\
Tertiary & 22 & 55 \\
Others & 3 & 7.5 \\
Total & 40 & 100 \\
\hline
\end{tabular}

Source: Field Survey, 2021

Table 4 above indicates the educational qualification of the sampled respondents. Clearly, respondents with tertiary education corresponding to $55 \%$ dominated participation in the activities of NGOs in the study area. They are followed by secondary with 10 respondents or $25 \%$ of the total while respondents with only primary education form an insignificant proportion of $12.5 \%$. Thus, an overwhelming majority of the respondents $(80 \%)$ have at least secondary school education. The implication here is that majority of the sampled respondents are educated. It may be that they decided to engage in the activities of the NGO a s they could not secure appropriate paid employment.

Table 5. Major Activities of the NGOs

\begin{tabular}{|l|}
\hline Major Activities of the NGOs in the Area \\
\hline Poverty Reduction \\
Micro Credit \\
Relief Services \\
Employment Creation \\
Capacity Building \\
Skills Development \\
\hline
\end{tabular}




\section{Grouping}

Source: Interview, 2021

Table 5 contains summary of major economic activities undertaken by the NGOs in the study area. Result from semi-structured interview has shown that the NGOs has taken some significant initiatives to handle the poverty situation in the study area considering certain aspects such as speedier economic growth achievement process, human resource development and specific target setting for poor. As a part of these combined strategies, the NGOs have undertaken some key activities which are as follows: essential role for humanitarian development through joint analysis and seeking solution through different seminars and workshop, joint social activities, and application of socio-economic projects. Besides, they have introduced certain essential concepts like developing small groups; credit based cooperatives for homeless/landless etc. and thus has strengthened the root of organizational structure for rural poverty.

In order to encourage the rural poor to participate in different economic activities and to increase their income through employment generation, the NGOs have created employment in two ways. Employment in their own organization as staff and secondly, they provide loans and management assistance to individuals, which create new employment opportunity. Besides they have provided inputs, technical and skill training and development facilities to poor youths to get self-employment. Thus they have significantly contributed in eradication of poverty by providing the above-mentioned essentials. One very important and effective innovation by the NGOs is the strategy of organizing group wise meeting. As a result, participation of the true beneficiaries and direct objective setup is possible to achieve economic target. Besides, it is an effective element in making the loan scheme to economically empower the poor successful. Overall economic development is essential for poverty eradication at both urban and rural levels. Besides employment generation, per head income and scheme to increase savings is required so that a sustainable development and poverty reduction can be seen for the poor. Microfinance is another important sector that the NGOs have fully utilized in reaching out to the poor youths. Their roles in this sector, has immensely contributed to alleviating poverty among the poor.

Capacity building is another NGOs' strategy and role that helps to bridge a gap between the haves and have not in society. Capacity building is an approach to development that builds independence. The provision of food and non-food items during emergency periods and war time and other disasters periods, often see NGOs functions as important one. The provision of these items is short run but very significance in alleviating poverty. The NGO has extended role to include peace building. This crucial role played by NGOs in the restoration of peace in war and disaster affected zones is worth noticeable. The presence of $\mathrm{NGO}^{\mathrm{ee}} \mathrm{s}$ led to the restoration of fair peace as their propagation of the human rights law, and their involvement in the disarmament, demobilization and reintegration programmes, is fostering cooperation among the warlords. Through the functions of providing microfinance, initiating capacity building and self -reliance, peace building projects, relief services during emergencies, the NGOs have bridged the gap of poverty in Makurdi.

Table 6. Benefits from the NGOs

\begin{tabular}{|l|l|l|}
\hline Major Benefits from the & Number of Respondents & Percentages (\%) \\
\hline
\end{tabular}




\begin{tabular}{|l|c|c|}
\hline NGOs & & \\
\hline Employment & 10 & 25 \\
Loans & 10 & 25 \\
Relief materials & 8 & 20 \\
Skills & 6 & 15 \\
Grouping & 6 & 15 \\
Total & 40 & 100 \\
\hline
\end{tabular}

Source: Field Survey, 2021

Table 6 shows some of the benefits the sampled respondents have benefited from participating in the activities of the NGOs. The table shows 10 respondents representing $25 \%$ said they have benefitted in terms of employment. Another 10 respondents, corresponding to $25 \%$ benefitted from loans. This is to enable them start up their businesses and permanently engage themselves. 8 respondents $(20 \%)$ got relief materials from the NGOs. This is also capable of reducing their dependency on government and family members there by, reducing their relative poverty status. 6 respondents corresponding to $15 \%$ acquired additional skills relating to different occupations such as soap making and tailoring. Another 6 respondents (15\%) got trained in management and coordination of groups. It is believed that NGOs easily gets to groups than individuals when they intend to intervene to better their lives. On the average, what the respondents have benefitted has equally corresponded to what the NGO has provided for them as earlier presented in Table 5.

Table 7. Respondents Occupation before Activities of the NGOs

\begin{tabular}{|c|c|c|}
\hline Occupation & $\begin{array}{ll}\text { Number } & \text { of } \\
\text { Respondents } & \end{array}$ & Percentages $(\%)$ \\
\hline Farming & 5 & 12.5 \\
\hline Business & 1 & 2.5 \\
\hline Civil Servant & 2 & 5 \\
\hline Unemployed & 32 & 80 \\
\hline Total & 40 & 100 \\
\hline
\end{tabular}

Source: Field Survey, 2021

Table 7 shows what the respondents were doing before participating in the various activities of the NGO in Makurdi. Results show that 32 respondents representing $80 \%$ were completely unemployed. $5(12.5 \%)$ were farmers while $1(2.5 \%)$ and $2(5 \%)$ respondents were into business and civil servants. This result entails that the NGOs conspicuously targeted the unemployed youths in Makurdi to empower and improve their income status. The onus is now on the researchers to examine the income status of the respondents after participation in the activities of the NGOs to establish whether income has increased or not 
Table 8. Major Problems of the NGOs

\begin{tabular}{|l|}
\hline Major Problems of the NGOs \\
\hline Finance \\
Small Coverage \\
Poor Awareness \\
Poverty \\
Poor Skill Development \\
Diversion of Loans \\
\hline
\end{tabular}

Source: Interview, 2021

Table 8 above displayed the major problems confronted by the NGOs in delivering to her mandate in the study area. One of the biggest challenges according to the NGOs was finance to execute all her programmes as well as disburse to beneficiaries as loans and grants. Furthermore, it is also rare for NGOs projects to be financially self sufficient. They only make an impact in a number of ways to complement government and individual efforts. Another problem was in the area of coverage. The activities are only limited to youths in Makurdi while the majority youths are residing outside the state capital. This is in addition to the fact that most youths in Makurdi are not yet aware of the activities of these NGOs. It is found that while NGOs projects reach the poor people, they tend not to reach down to the very poorest. This entails that most respondents were extremely poor such that the effort of the NGOs could not make any impact to their lives. NGOs projects also tend to be small scale. The total numbers assisted are also small. Finally, although the NGOs trained many respondents but some could not comprehend the essence of the skills impacted in them, just as many could not repay the mini loans given to them. In fact, many diverted their loans to other uncontrollable activities that cannot innovate their living or economic activities. Therefore, because of these limitations, the role of NGOs in alleviating poverty in Makurdi cannot be exaggerated.

\section{Conclusion and Recommendations}

\subsection{Conclusion}

Despite the challenges confronting NGOs in carrying out its activities in the study area, the respondents confirm maximum benefits in terms of increased income, use of good transportation means, good accommodation, feeding and sleeping materials. This is in line with the basic need approach which defined poverty reduction in terms of ability to have access to certain basic needs like transportation, good accommodation and feeding, good sleeping materials and improved income. On this basis, the NGOs have reduced poverty amongst youth in the study area.

\subsection{Recommendations}

On the basis of the findings of this study, the following policy recommendations are made: 
1. Massive awareness campaigns are still required for the people of Makurdi to come forward and benefit from the numerous activities of NGOs in the study area.

2. The beneficiaries of NGOs need to be more sincere in their dealings with their organization. NGOs are not political parties or government, as such soft loans obtained from them must be serviced to ensure continuity and further benefits.

3. The beneficiaries are also urged to take their training seriously. This is an era of promoting entrepreneurship and financial independence and it is only through such skills that they can propel themselves into entrepreneurship and financial independence.

4. With this crucial impact on the host community, the NGOs should seek for more sources of funding including the international community to enable it fund diversified economic activities of the vulnerable people in the country.

5. With additional funding, the NGOs can expand its scope to cover the entire Benue state youth as against the present limited operation in Makurdi local government.

\section{References}

Anyanwu, J. C. et al (1997) The Structure of the Nigerian Economy. Joanne Publishers Onitsha, Nigeria

Betiang, P. (2010): An Impact Assessment of Federal Government Policies on Poverty Reduction in Northern Senatorial Zone of Cross Rivers State, Nigeria. A PhD Thesis Submitted to University of Calabar, Nigeria

Beto, C. and Leonorah, T. N. (2016) The Role of Non-Governmental Organizations (NGOs) in Poverty Reduction: A case of Zambézia Province. Imperial Journal of Interdisciplinary Research. 2(6):1-8

Brass, J. N. (2011) Blurring boundaries: the integration of NGOs into governance in Kenya', Governance: An International Journal of Policy, Administration, and Institutions 25(2):209-235.

Brass, J. N. (2012) Why do NGOs go where they go? Evidence from Kenya, World Development, 40(2):387-401.

Central Bank of Nigeria (2010) The Changing Structure of the Nigerian Economy and Implication for Development. Abuja, Nigeria

Clarke, G. (1998) Non-governmental organizations (NGOs) and politics in the developing world, Political Studies XLVI: 36-52.

Devi, U. R. (2013) An analysis study on the role of NGOs in the poverty reduction of India. Journal of Arts, Science \& Commerce. 4(1):128-137

Drabek, A. G. (1987). Development alternatives: The challenge for NGOs-an overview of the issues. World Development, 15, ix-xv.

Gill, A. (1997). Striking a Balance: A Guide to Enhance the Effectiveness of NonGovernmental Organizations in International Development. London: Earthscan Publication.

Gisaor, V. I. (2016) NGOs and poverty reduction in Nigeria: A case study of selected NGOs in Wukari LGA, Taraba State. Accepted for publication in Journal of FHMSS. FUW Nigeria. 
Gisaor, V. I. (2020) NGOs and Poverty Reduction in Nigeria. A Paper Presented at the Launching of Mama Ngihuan Foundation in Makurdi, Benue State.

Hearn, J. (2007) Roundtable: African NGOs: the new compradors?, Development and Change 38(6): 1095-1110.

Hulme, D. and Nicola, B. (2012) The role of NGOs and civil society in development and poverty reduction. BWPI Working Paper 171

International Monetary Fund, (2020): "COVID-19 and Poverty". World Economic Outlook: May 2020. Washington DC, IMF, pp36-39.

Jhingan, M. L. (2007) Advanced Economic Theory. Vrinda Publication(s), New Delhi, India

Lewis, D. (1998). Development NGOs and the challenge of partnership: changing relations between North and South. Social policy \& administration, 32(5), 501-512.

Mauri, G. (2013). Lutar Contra a Pobreza e a Exclusão Social: O Contributo das ONG. São Paulo, Editor. Brazil.

Mohammed, A. A. (2008). Reflections on the Victory and Crisis of Democracy: Democracy and Development. University of Irolin, Nigeria.

Nair, T. (2011). Institutionalizing microfinance in India: an overview of strategic issues. Economic and Political Weekly 36(4): 399-404.

Newman C. E. (2012) Role of Non-Governmental Organizations in rural development: A study of the six listed NGOs in Rivers State, Nigeria. An unpublished Dissertation of University of PortHarcourt, Nigeria.

Oke, J. T. and Adeyemo, R. (2007) Impact of Non-governmental Organizations (NGOs) on Rural Poverty Alleviation in South-western Nigeria. International Journal of Applied Agricultural and Apicultural Research 4 (1\&2): 1-13.

Omofonmwan, S. I. and Odia, L. O. (2009) The Role of Non-Governmental Organisations in Community Development: Focus on Edo State-Nigeria. Anthropologist, 11(4): $247-$ 254

Oriola, E. O. (2006) Effects of Irrigation on Soils of a Sub Humid Part of Kwara State, Nigeria. CENTERPOINT. A Journal of Intellectual, Scientific and Cultural Interest University of Ilorin. 12(1): 52-62.

Rose, P., (2011) 'Strategies for engagement: government and national non-government education providers in South Asia', Public Administration and Development 31: 294305.

Rosenberg, A., K. (2008), 'Government-NGO collaboration and sustainability of orphans and vulnerable children projects in southern Africa', Evaluation and Program Planning 31:51-60.

Royemomi, J. (2013). Redução da Pobreza no Mundo. Que Estratégias. Brazil: S.Paulo.

Umoh, GS. and Ibanga, I.O. (1997): "An alternative microcredit delivery model for poverty alleviation in Nigeria". In: Poverty alleviation in Nigeria, Selected papers for the 1997 Annual Conference of the Nigerian Economic Society, pp 521-532. 
United Nations Development Programme (UNDP) (2004) Millennium Development Goals. Human Development Report (2004) New York. Oxford University Press.

World Bank (2003) World Bank Development Indicators 2003 The World Bank Washington D.C 